\title{
The influence of soluble salts content on the performance of an epoxy coating system via accelerated corrosion tests
}

\author{
Camila Aparecida Zimmermann ${ }^{1,2}$, Luciano André Deitos Koslowski ${ }^{3}$, \\ Maria Inês Siqueira Araújo ${ }^{1}$, Marcia Luciane Lange Silveira ${ }^{1}$
}

\footnotetext{
${ }^{1}$ Department of Chemical Engineering Joinville Campus - University of the Region of Joinville (UNIVILLE). Rua Paulo Malschitzki, 10 - Zona Industrial Norte, CEP: 89219-710, Joinville, SC, Brazil.

${ }^{2}$ Corrosion Laboratory, Innovation and Technology Department - Weg Tintas LTDA - BR 280, km 50, CEP: 89270-000, Guaramirim, SC, Brazil.

${ }^{3}$ Department of Civil Engineering Ibirama Campus - Santa Catarina State University (UDESC). Av. Getúlio Vargas 2822 - Bela Vista, CEP: 89140-000, Ibirama, SC, Brazil.

e-mail: mila.zimmermann@gmail.com, luciano.koslowski@udesc.br, maria.ines@univille.br, marcia.luciane@univille.br
}

\begin{abstract}
It is generally accepted that surpassing a threshold value of water-soluble salts at the substrate/coating interface can impart premature failure in painted structures. The Coatings industry has an identified need in defining a maximum allowable soluble salts content, however, a variety of threshold values are found in published data. Based on that, this work aims at evaluate the effect on epoxy coating performance of three different ranges of soluble salts content taking into account the maximum allowable values specified by NORSOK M501 and IMO PSPC MSC.215, two important standards of naval and offshore sectors.

Blast-cleaned carbon steel specimens contaminated with sodium chloride solutions diluted in methanol ranging 20, 50 and $100 \mathrm{mg} / \mathrm{m}^{2} \mathrm{NaCl}$ were painted with two epoxy-amine paint coats. Samples were evaluated by cathodic disbondment, water immersion at $40^{\circ} \mathrm{C}$, pull-off adhesion strength and cyclic corrosion tests.

Larger blisters and loss of adhesion were observed as the soluble salts content at the interface increased. Although, it was not possible to find a critical level of soluble salts even considering data about similar coating systems. A safe soluble salt content must be chosen based on tests that closer reproduce service and environmental conditions to which a painted structure will be exposed.
\end{abstract}

Keywords: Carbon steel, Corrosion, Soluble Salts Content, Epoxy, Paint.

\section{INTRODUCTION}

Water-soluble salts, such as chlorides and sulphates, once deposited on steel structures will be hardly completely removed, even by abrasive blast-cleaning [1-3]. They are considered by the coatings industry all over the world as responsible for the detriment of painted steel structures when a threshold concentration is exceeded [4-8].

The presence water-soluble salts at the metal/coating interface promotes osmosis due to their hygroscopic nature $[5,9,10]$. As water penetrates through the coating, that is a semi-permeable membrane, it dissolves the soluble salts resulting in a strong electrolyte that promotes underfilm corrosion [11-13]. Hence, premature failures such as osmotic blistering, cathodic disbondment, adhesion loss, corrosion and delamination under the film are observed [6, 9, 13-15]. Even a coating with improved barrier characteristics to reduce water diffusion may not be enough to stop corrosion from a contaminated substrate with soluble salts [10].

A big number of specifications and surface preparation procedures were developed trying to prevent such premature failures resulting in a variety of different acceptable levels of soluble salts content [2-4, 1618]. An example is the Technical Report ISO/TR 15235, developed by the International Standard Organization (ISO) that presents a collection of results from scientific works and data from coatings manufacturers and users. According to this document, there is a wide variation in the existing knowledge regarding soluble salts content and, its effects on the performance of coatings and related products [1]. Nowadays, the problem remains unsolved since the coating industry did not define an acceptable soluble salt content or a global ref- 
erence standard with levels that could be easily applied to reduce the risks of failure $[4,17,18]$.

It is expected that different coatings systems behave equally different at various soluble salts levels and exposure conditions [19]. In the best of our knowledge, however, there is no coherence for maximum allowable soluble salts content even considering similar coating systems, with similar chemical binder, film thickness, substrate and surface preparation. Consensus cannot be found even in worldwide standards for coating systems approval. The standards IMO PSPC MSC.215 (82) [20] (naval sector) and the NORSOK M501 [21] (offshore sector) specify allowable soluble salts contents of 50 and $20 \mathrm{mg} / \mathrm{m}^{2} \mathrm{NaCl}$, respectively. Considering the published literature, for an epoxy system, which is one of the most important anticorrosion coatings [22], with a dry film thickness within 200 to $300 \mu \mathrm{m}$, the soluble salts content considered of low risk vary between $<10$ and $164 \mathrm{mg} / \mathrm{m}^{2} \mathrm{NaCl}[1,15,23,24]$.

Lee et al. [23], for example, evaluated the effect of soluble salt contents within the range of 0 (virtually) up to $200 \mathrm{mg} / \mathrm{m}^{2} \mathrm{NaCl}$ on fully-blasted steel. They recommended a maximum soluble salts content of 100 $\mathrm{mg} / \mathrm{m}^{2} \mathrm{NaCl}$. Axelsen and Knudsen [24] carried out a study based on NORSOK M-501 [22]. They investigated the effect of water-soluble salts on two commercially available epoxy systems and a clear lacquer in an interval of 5 up to $300 \mathrm{mg} / \mathrm{m}^{2} \mathrm{NaCl}$. On one hand, they showed that the soluble salts content had little effect on the corrosion around the scribe in cyclic corrosion test and cathodic disbondment. On the other hand, the authors concluded that the soluble salts content should be kept as low as possible and that the value proposed by NORSOK M-501 is suitable. Moreover, Baek et. al [15] studied the effect on the performance of one epoxy system from 0 (virtually) up to $660 \mathrm{mg} / \mathrm{m}^{2} \mathrm{NaCl}$ also based on the NORSOK M-501 [21] specifications. They settled a soluble salt limit of $115 \mathrm{mg} / \mathrm{m}^{2} \mathrm{NaCl}$ based on results of cyclic corrosion test, approximately 6 times higher than NORSOK M-501 recommended value.

Therefore, based on this diversity of values and ranges found in the literature, this work aims at investigate the influence of soluble salts content on the performance of a two-coat epoxy system applied on blastcleaned carbon steel based on the limits specified by IMO PSPC MSC.215 (82) [20] and NORSOK M-501 [21] standards and the technical report ISO/TR 15235 [1].

\section{MATERIALS AND METHODS}

\subsection{Materials}

Sodium chloride ( $\mathrm{NaCl}, \geq 99,0 \%$, Anidrol) was used to prepare solutions for the contamination process, salt spray and cathodic disbondment tests. Sodium sulphate $\left(\mathrm{Na}_{2} \mathrm{SO}_{4}, \geq 99,0 \%\right.$, Dinâmica Química) and sodium carbonate $\left(\mathrm{Na}_{2} \mathrm{CO}_{3}, \geq 99,5 \%\right.$, Química Moderna) were used just in cathodic disbondment solution. Deionized water was used in all experiments (MB 400 ion exchange resin, Purolite) if not mentioned otherwise.

\subsection{Preparation of specimens for tests}

\subsubsection{Blast-cleaning}

Steel panels were degreased with xylene and blasted with angular and spherical steel grit in the proportion $75: 25$ to Sa $2 \frac{1}{2} 2$ according to ISO 8501-1 [25]. A total of thirty-six specimens of $(100 \times 150 \times 3) \mathrm{mm}$ were prepared for tests of soluble salts content, pull-off adhesion, cathodic disbondment and water immersion, and other fifteen samples of $(75 \times 150 \times 30) \mathrm{mm}$ for cyclic corrosion test.

\subsubsection{Contaminating procedure}

The procedure for specimens' contamination to achieve the proposed range of soluble salts was based on method described by Flores et al. [26], Fuente et al. [7, 8, 27] e Baek et al. [15].

Three contamination ranges were selected to investigate the effects of soluble salts on steel before painting. The condition A with a soluble salts level measured as sodium chloride up to $20 \mathrm{mg} / \mathrm{m}^{2}$ was chosen to evaluate the limit proposed by NORSOK M-501 [22]. The condition B, with a soluble salt level from 21 up to $50 \mathrm{mg} / \mathrm{m}^{2}$ was selected to test the IMO PSPC MSC.215(82) [20] specification. And the condition C, with a soluble salt content from 51 up to $100 \mathrm{mg} / \mathrm{m}^{2}$ was selected trying to reproduce some of the highest values mentioned by coating manufacturers according to ISO/TR 15235 [1].

Solutions for blast-cleaned specimens' contamination were prepared by dissolving $\mathrm{NaCl}$ analytical grade in $10 \mathrm{~mL}$ of deionized water in a beaker, at an amount previously weighed on analytical balance according to the required solution concentration presented in Table 1 . The soluble salt content generally found on metal surface before the intentional contamination was not subtracted from the desired content as pre-tests 
showed that the ranges could be fully met without this subtraction.

Table 1: Data for contamination process

\begin{tabular}{l|l|l|l|l|l}
\hline \multirow{2}{*}{ CONDITION } & $\begin{array}{l}\text { SPECIMEN } \\
\text { SIZE }(\mathbf{m m})\end{array}$ & AREA $\left(\mathbf{m}^{2}\right)$ & $\begin{array}{l}\text { TARGET VALUE } \\
\left(\mathbf{m g} / \mathbf{m}^{2} \mathbf{~ N a C l}\right)\end{array}$ & $\begin{array}{l}\text { NaCI } \\
\text { SOLUTION }(\mathbf{g} / \mathbf{L})\end{array}$ & $\begin{array}{l}\text { APPLIED VOLUME ON } \\
\text { THE SURFACE FOR } \\
\text { CONTAMINATION (mL) }\end{array}$ \\
\hline \multirow{3}{*}{$\mathrm{A}$} & $100 \times 150$ & 0.01500 & 16 & 0.300 & 0.8 \\
\cline { 2 - 7 } & $75 \times 150$ & 0.01125 & 16 & 0.300 & 0.6 \\
\hline \multirow{2}{*}{$\mathrm{B}$} & $100 \times 150$ & 0.01500 & 40 & 0.750 & 0.8 \\
\cline { 2 - 7 } & $75 \times 150$ & 0.01125 & 40 & 0.750 & 0.6 \\
\hline \multirow{2}{*}{$\mathrm{C}$} & $100 \times 150$ & 0.01500 & 100 & 1.875 & 0.8 \\
\cline { 2 - 7 } & $75 \times 150$ & 0.01125 & 100 & 1875 & 0.6 \\
\hline
\end{tabular}

The content was transferred to a $2 \mathrm{~L}$ volumetric flask and diluted with $98 \%$ methanol, in which sodium chloride presents a higher solubility compared to ethanol, $13.75 \times 10^{-3}$ and $0.55 \times 10^{-3}$, respectively, by weight fraction [28]. Methanol was used aiming to promote a rapid evaporation and prevent the formation of fast surface corrosion (flash rust) during specimens' contamination, which could compromise the test results [35].

Sodium chloride $(\mathrm{NaCl})$ was used as a reference since it represents the major cause of premature failure of coatings due to its high solubility and hygroscopicity. Furthermore, it is the soluble salt most found on contaminated substrates $[5,12,16,29]$.

Both sample sides were contaminated with the methanolic solutions previously prepared in appropriate concentrations to obtain the target values presented in Table 1. An appropriate volume of solution, Table 1 , enough to wet the substrate evenly, without leaving accumulation, was transferred with a $1 \mathrm{~mL}$ graduated pipette and deposited on one of the sides to be contaminated. The solution spreading, and the substrate wetting were done with a glass rod.

Samples were dried in an electric oven at $70^{\circ} \mathrm{C}$, for 3 minutes. After removal from the oven, we waited until the test specimen reached room temperature $\left(24 \pm 2{ }^{\circ} \mathrm{C}\right)$ to proceed with the contamination of the other side following the same steps.

\subsubsection{Determination of soluble salts content}

Extraction can be performed by multiple techniques, like swabbing method, Bresle method and the Mayne one, with efficiency between 90 and 100\% in analyses on surfaces without corrosion [7, 26]. Similarly, the salts content determination in a water extract can be performed by ion selective electrodes, spectrophotometer, titration or conductivity meter and others [10].

The Bresle extraction method and measurement by a conductometer were chosen because they are specified by the worldwide standards IMO PSPC MSC.215(82) [20] and NORSOK M-501 [21]. Furthermore, is a simple and cheap method, therefore one of the most used [5, 29].

Immediately after abrasive blast-cleaning two samples were randomly chosen for verification of the soluble salts content. According to the industrial practice a total of $10 \%$ of prepared samples for performance tests per batch must have the soluble salts content evaluated. Thus, two samples per condition were considered enough as they correspond to $10 \%$ of the number of prepared samples.

TQC Bresle adhesive patches were used with a compartmented area of $1250 \pm 13 \mathrm{~mm}^{2}$, placed in the center of each sample. A $3 \mathrm{~mL}$ syringe with needle was used to remove internal air from the patch and then filled with $2.5 \mathrm{~mL}$ of deionized water. From this volume, $1.5 \mathrm{~mL}$ was injected into the conductometer measuring cell to determine the initial conductivity (blank value).

This volume of deionized water $(1.5 \mathrm{~mL})$ was drawn to have again $2.5 \mathrm{~mL}$ for injection through the latex membrane and the foam, in the inner compartment of the patch without removing the syringe. The adhesive was massaged for a minute and then proceeded the suction and reinjection of the liquid twice a minute, for 3 minutes. Finally, the water was again collected, and $1.5 \mathrm{~mL}$ injected in the measuring cell to determine the final conductivity.

The conversion of conductivity to soluble salts content in $\mathrm{mg} / \mathrm{m}^{2} \mathrm{NaCl}$ was obtained according to 
Equation 1, from ISO 8502-9 [30]:

$$
\rho_{\mathrm{A}}=\mathrm{c} . \mathrm{v} .\left(\gamma_{\mathrm{f}}-\gamma_{\mathrm{i}}\right) \cdot 100 / \mathrm{A}
$$

Where $\rho_{A}$ : soluble salts content; c: empirical constant equal to $5 \mathrm{~kg} / \mathrm{m}^{2} . \mathrm{s}^{1}$ under normal conditions; v: volume injected into the adhesive patch in millilitres; $\gamma_{f}$ : final conductivity measurement of solution extracted from the patch; $\gamma_{i}$ : initial conductivity measured of deionized water (blank value); A: analysed area (corresponding to the adhesive compartment area) in $\mathrm{mm}^{2}$.

The same steps were repeated for the three target contamination conditions.

\subsubsection{Painting procedure}

A coating system suitable for the proposed investigation was selected based on the specifications of coating system 3B of NORSOK M-501 [21]. This is a coating system that acts only as a physical barrier specified for application in ballast water carbon steel tanks, which is one of the most corrosive environments. The coating system is detailed in Table 2.

Table 2: Coating system data

\begin{tabular}{l|l}
\hline SUBSTRATE & Steel hot rolled, ASTM A36-08 (Usiminas) \\
\hline SURFACE PREPARATION & Abrasive blast-cleaned at Sa 2 1/2 [25] \\
\hline ROUGHNESS PROFILE $(\boldsymbol{\mu m})$ & Between 50 and 80 \\
\hline MANUFACTURER & Weg Tintas LTDA. (Guaramirim, Brazil) \\
\hline FIRST COAT & Primer-top coat epoxy amine two pack Grey N 6.5 \\
\hline NOMINAL DRY FILM THICKNESS - NDFT $(\boldsymbol{\mu m})$ & 150 \\
\hline SECOND COAT & Primer-top coat epoxy amine two pack White N 9 \\
\hline NOMINAL DRY FILM THICKNESS - NDFT $(\boldsymbol{\mu m})$ & 150 \\
\hline
\end{tabular}

Paints were prepared according to the manufacture's technical datasheet. Both coats were applied with a conventional spray gun (DeVilbiss JGA-503) respecting the overcoating period on both panels' sides.

Seven days after the second coat application, the dry film thickness was measured with the magnetictype thickness gauge Tecnomedição SME-CII PLUS. A reduction factor of $25 \mu \mathrm{m}$ was considered in each measurement according to ISO 19840 [31] recommendation, as a roughened surface has a higher volume to be completed when compared to a flat one.

The test side of each panel was selected based on measurements of dry film thickness (DFT) in five points considering the acceptance criteria of ISO 19840 [31]. coating.

All specimens for the accelerated corrosion tests had their borders protected with the same applied

\subsection{Tests}

Tests were carried out according to the performance tests listed in the Table 3 . All tests were carried out in a laboratory at $23 \pm 2{ }^{\circ} \mathrm{C}$ and relative humidity of $55 \pm 5 \%$.

Table 3: Performance tests

\begin{tabular}{l|l|l|l|l}
\hline TEST & $\begin{array}{l}\text { STANDARD } \\
\text { PROCEDURE } \\
\text { FOR TESTING }\end{array}$ & $\begin{array}{l}\text { ESTIMATED } \\
\text { LENGTH OF } \\
\text { TIME }(\mathbf{h})\end{array}$ & $\begin{array}{l}\text { DIMENSIONS } \\
\text { OF SPECIMENS } \\
\mathbf{( m m})\end{array}$ & $\begin{array}{l}\text { NUMBER OF } \\
\text { SPECIMENS PER } \\
\text { CONDITION }\end{array}$ \\
\hline Pull-off adhesion & ISO 2812-2 [32] & 24 & $100 \times 150 \times 3$ & 1 \\
\hline $\begin{array}{l}\text { Cathodic disbondment by impressed } \\
\text { current }\end{array}$ & ISO 4624 [33] & 720 & $100 \times 150 \times 3$ & 3 \\
\hline Immersion in deionized water at $40^{\circ} \mathrm{C}$ & ASTM G-8 [34] & 3000 & $100 \times 150 \times 3$ & 3 \\
\hline Cyclic corrosion & ISO 20340 [35] & 4200 & $75 \times 150 \times 3$ & 3 \\
\hline
\end{tabular}


Rusting and blistering grades eventually observed in accelerated corrosion tests were classified according to standards ISO 4628-3 [36] and ISO 4628-2 [37], Tables 4 and 5, respectively.

Table 4: Rusting grade classification

\begin{tabular}{l|l}
\hline DEGREE & RUSTED AREA (\%) \\
\hline Ri 0 & 0 \\
\hline Ri 1 & 0.05 \\
\hline Ri 2 & 0.5 \\
\hline Ri 3 & 1 \\
\hline Ri 4 & 8 \\
\hline Ri 5 & 40 a 50 \\
\hline
\end{tabular}

Table 5: Blistering grade classification

\begin{tabular}{l|l|l|l}
\hline GRADE & QUANTITY & GRADE & SIZE \\
\hline 0 & None & S0 & Not visible under x 10 magnification \\
\hline 1 & Very few & S1 & Only visible under magnification up to x 10 \\
\hline 2 & Few & S2 & Just visible with normal corrected vision \\
\hline 3 & Moderate & S3 & Clearly visible with normal corrected vision (up to $0.5 \mathrm{~mm}$ ) \\
\hline 4 & Considerable & S4 & 0.5 to $5 \mathrm{~mm}$ \\
\hline 5 & Dense & S5 & Larger than $5 \mathrm{~mm}$ \\
\hline
\end{tabular}

\subsubsection{Pull-off adhesion test}

Adhesion of a protective coating is an important prerequisite for corrosion protection effectiveness [22].

Dollies of $20 \mathrm{~mm}$ diameter were bonded with Scotch Weld epoxy adhesive DP-460 3M® on the specimens' surface. The coating and dollies surfaces were previously sanded with sandpaper grade 240 . After the epoxy adhesive curing of $24 \mathrm{~h}$, the pull-off adhesion test was carried out with a hydraulic tester device Positest AT-A applying a tensile stress rate of $1 \mathrm{MPa} / \mathrm{s}$.

Failures percentage by type (adhesion/ cohesion) were determined according to ISO 4624 [33] as illustrated in Figure 1, using the software DraftSight 2013 for area calculation.

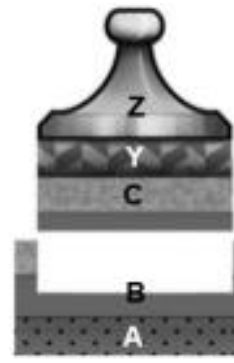

Cohesive fracture (within a layer)

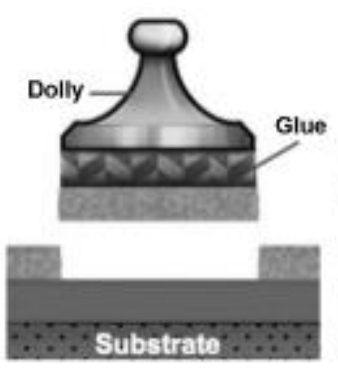

Adhesive fracture (between layers)

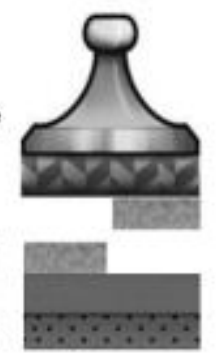

Adhesive fracture

$50 \%$ between glue and

coatign $(\mathrm{C} / \mathrm{Y})$
Key

A: Substrate

B: first coat

C: second coat

D: third coat and so on

Y: glue

Z: dolly

Figure 1: Evaluation and classification of failure types developed in pull-off test. An adhesive failure is reported by a bar between the letter that indicate the coats where the failure happened. A cohesive failure is reported by the coat letter where the failure happened.

Source: Adapted from [38].

\subsubsection{Cathodic disbondment by impressed current}

The cathodic disbondment test is a powerful way to evaluate the synergic effect of cathodic protection and 
the presence of soluble salts [23]. The explanation for the cathodic disbondment effect is unclear [24, 39]. It is suggested that the integrity of the interaction between metal-polymer is compromised by $\mathrm{pH}$ increasing due to the reactions 2 and 3 [12]:

In the anode:

$$
\mathrm{Fe} \rightarrow \mathrm{Fe}^{2+}+2 \mathrm{e}^{-}
$$

In the cathode, in non-aerated medium:

$$
2 \mathrm{H}_{2} \mathrm{O}+2 \mathrm{e}^{-} \rightarrow \mathrm{H}_{2}+2 \mathrm{OH}^{-}
$$

The oxygen reduction reaction in the coating pores (reaction 2) and the migration of $\mathrm{Na}^{+}$ions present in the test solution leads to the accumulation of $\mathrm{NaOH}$. Alkalinization can hydrolyses the interfacial bonds between substrate/coating or even the paint itself, degrading it [40]. Another adverse effect is the generation of hydrogen gas (reaction 2) arising the pressure and consequently causing disbondment [23].

The cathodic disbondment by impressed current was performed as mentioned in Table 3, by applying a voltage between minus 1.378 to $1.478 \mathrm{~V}$ based on saturated calomel reference electrode (SCE). The voltage was adjusted individually using potentiometers.

Specimens were prepared for test by performing a circular defect with a cutter up to the interface metal/coating, with initial diameter $\left(d_{i}\right)$ of $7 \mathrm{~mm}$, centred in relation to width and $50 \mathrm{~mm}$ from the bottom edge. Specimens had $2 / 3$ of their test area immersed in saline solution consisting of $1 \%$ by weight of sodium chloride, sodium sulphate and sodium carbonate in freshly potable water as recommended by ASTM G-8 [34].

After 30 days, the specimens were rinsed with potable water at ambient temperature and reconditioned for 24 hours at $23 \pm 2{ }^{\circ} \mathrm{C}$ and relative humidity of $55 \pm 5 \%$, before detachment process.

To proceed with the delamination around the defect, four incisions were made crossed over the original defect and the disbondment was conducted with a sharp, thin-bladed knife.

The equivalent circular diameter (ECD) in mm was calculated according to the equation 4 based on ASTM G-8 [34].

$$
\text { ECD: }\left(\left(\mathrm{A}_{\mathrm{t}} /(\pi / 4)\right)^{1 / 2}\right)-\mathrm{d}_{\mathrm{i}}
$$

The total area $\left(A_{t}\right)$ detached was determined with the software DraftSight 2013.

\subsubsection{Immersion in deionized water at $40^{\circ} \mathrm{C}$}

Water immersion test is a common practice for accelerate adhesive failures and to estimate the blistering resistance $[16,23]$.

Water immersion resistance test was carried out by immerging $2 / 3$ of specimens' length at an angle of $20 \pm 5^{\circ}, 3 \mathrm{~cm}$ apart from each other and from the walls, in a fiberglass tank (EQUILAM EQTI-120) made of inert material. A submerged aquarium pump (Sarlo Better, SB1000a) was used for mechanical circulation at a flow rate of $1000 \mathrm{~L} / \mathrm{h}$, maintained at $40 \pm 1^{\circ} \mathrm{C}$.

\subsubsection{Cyclic corrosion test}

The cyclic corrosion test combining saline fog and exposure to UV-A artificial weathering (340 $\mathrm{nm})$ was chosen because it provides the best correlation with the natural severe marine environment as already demonstrated elsewhere [41]. Since it includes environmental variations such as wet and dry periods, with and without UV rays, it is closer to what happens in the natural environment, without maintaining a corrosive environment on a permanent basis [42].

Cyclic corrosion test was carried out complying with ISO 20340 [35], composed by:

- 72 hours of neutral salt spray, according to 9227 [43];

- 24 hours at $-20{ }^{\circ} \mathrm{C}$ in a climatic chamber (ESPEC EPL-2H) and;

- 72 hours of accelerated weathering cycles complying with ISO 16474-3 [44], in a weathering chamber (Q-LAB, model QUV/SE) with UV-A $340 \mathrm{~nm}$ lamps (Philips) of $40 \mathrm{~W}$. One cycle consists of $4 \mathrm{~h}$ of UV-A light at $60{ }^{\circ} \mathrm{C}$ and irradiance of $0.89 \mathrm{~W} / \mathrm{m}^{2}$ plus $4 \mathrm{~h}$ of condensation at $50^{\circ} \mathrm{C}$.

Specimens received a scribe line made manually using a suitable scratcher and a metal ruler, immediately before starting test. The scribe line was made parallel to its short dimension, $25 \mathrm{~mm}$ far from one of the 
short edges e $12.5 \mathrm{~mm}$ from the long edges, and $2 \mathrm{~mm}$ width.

After the exposure time, specimens were rinsed with potable water at ambient temperature and reconditioned for 24 hours at $23 \pm 2{ }^{\circ} \mathrm{C}$ and relative humidity of $55 \pm 5 \%$, before detachment process using a sharp, thin-bladed knife.

\section{RESULTS}

\subsection{Soluble salts content}

Soluble salts contents obtained by the Bresle extraction method and conductometer for the three conditions proposed is presented on the Table 6 .

Table 6: Soluble salts levels obtained after contamination of specimens

\begin{tabular}{l|l|l}
\hline CONDITION & $\begin{array}{l}\text { TARGET OF SOLUBLE SALTS CONTENT } \\
\left.\text { (mg/ } \mathbf{m}^{2} \mathbf{~ N a C l}\right)\end{array}$ & $\begin{array}{l}\text { SOLUBLE SALTS CONTENT AVERAGE } \\
\left(\mathbf{m g} / \mathbf{m}^{\mathbf{2}} \mathbf{~ a C l}\right)\end{array}$ \\
\hline A & Up to 20 & $13.4 \pm 0.8$ \\
\hline B & From 21 up to 50 & $48.4 \pm 0.8$ \\
\hline C & From 51 up to 100 & $96.2 \pm 8.1$ \\
\hline
\end{tabular}

The amounts of soluble salts attended the ranges proposed for comparative performance of test specimens.

The soluble salt content measured immediately after surface preparation was $13.4 \mathrm{mg} / \mathrm{m}^{2}$. To avoid that the largest value of the proposed range for condition $\mathrm{A}\left(20 \mathrm{mg} / \mathrm{m}^{2} \mathrm{NaCl}\right)$ was extrapolated, an additional surface contamination of the specimens belonging to this group was not carried out.

\subsection{Pull-off adhesion test}

Adhesion strength results and percentages of fractures types developed in the coating system are shown in Table 7.

Table 7: Adhesion strength values and percentages per failure type

\begin{tabular}{l|l|l|l|l}
\hline \multirow{2}{*}{ CONDITION } & \multirow{2}{*}{ DFT $(\boldsymbol{\mu m})$} & \multicolumn{4}{l}{ PULL-OFF STRENGTH } & \multicolumn{2}{l}{ DOLLY 03 } \\
\cline { 3 - 5 } & & DOLLY 01 & DOLLY 02 & $5.17 \mathrm{MPa}$ \\
$\mathrm{A}$ & \multirow{2}{*}{$290-305$} & $\begin{array}{l}5.68 \mathrm{MPa} \\
98.2 \% \mathrm{C} / \mathrm{Y}, 1.8 \% \mathrm{Y} / \mathrm{Z}\end{array}$ & $\begin{array}{l}5.26 \mathrm{MPa} \\
100 \% \mathrm{C} / \mathrm{Y}\end{array}$ & $0.4 \% \mathrm{~B} ; 99.6 \% \mathrm{C} / \mathrm{Y}$ \\
\hline \multirow{3}{*}{$\mathrm{B}$} & \multirow{2}{*}{$285-305$} & $10.66 \mathrm{MPa}$ & $\begin{array}{l}9.05 \mathrm{MPa} \\
100 \% \mathrm{C} / \mathrm{Y}\end{array}$ & $9.69 \mathrm{MPa}$ \\
& & $100 \% \mathrm{C} / \mathrm{Y}$ & $100 \%$ \\
\hline \multirow{2}{*}{$\mathrm{C}$} & \multirow{2}{*}{$245-300$} & $8.65 \mathrm{MPa}$ & $\begin{array}{l}8.81 \mathrm{MPa} \\
0.2 \% \mathrm{~A} / \mathrm{B} ; 0.5 \% \mathrm{~B} / \mathrm{C} ;\end{array}$ & $7.49 \mathrm{MPa}$ \\
& & $100 \% \mathrm{C} / \mathrm{Y}$ & $99.3 \% \mathrm{C} / \mathrm{Y}$ & $\mathrm{C} / \mathrm{Y}$ \\
\hline
\end{tabular}

Key: A: substrate; B: first coat; C: second coat; Y: glue; Z: dolly.

\subsection{Cathodic disbondment by impressed current}

The specimens' assessments after the test ending are shown in Table 8. 
Table 8: Results of cathodic disbondment test after $720 \mathrm{~h}$

\begin{tabular}{|c|c|c|c|c|c|}
\hline CONDITION & DFT $(\mu \mathrm{m})$ & $\begin{array}{l}\text { RUSTING } \\
\text { DEGREE } \\
\end{array}$ & $\begin{array}{l}\text { BLISTERING } \\
\text { DEGREE } \\
\end{array}$ & $\mathrm{ECD}(\mathrm{mm})$ & $\begin{array}{l}\text { PULL-OFF STRENGTH } \\
\text { AFTER TEST }\end{array}$ \\
\hline \multirow{3}{*}{ A } & $310-355$ & Ri 0 & 0 (S0) & 10.1 & $\begin{array}{l}9.4 \mathrm{MPa} \\
100 \% \mathrm{C} / \mathrm{Y}\end{array}$ \\
\hline & $265-330$ & Ri 0 & 0 (S0) & 11.3 & $\begin{array}{l}8.00 \mathrm{MPa} \\
100 \% \mathrm{C} / \mathrm{Y}\end{array}$ \\
\hline & $270-330$ & Ri 0 & $0(\mathrm{~S} 0)$ & 5.7 & $\begin{array}{l}11.09 \mathrm{MPa} \\
100 \% \mathrm{C} / \mathrm{Y}\end{array}$ \\
\hline \multirow{3}{*}{ B } & $285-310$ & Ri 0 & 0 (S0) & 13.0 & $\begin{array}{c}\text { 6.19 MPa } \\
33.2 \% \mathrm{~A} / \mathrm{B} ; 66.8 \% \mathrm{C} / \mathrm{Y} \\
\end{array}$ \\
\hline & $295-325$ & Ri 0 & 0 (S0) & 12.7 & $\begin{array}{c}5.14 \mathrm{MPa} \\
91.1 \% \mathrm{~A} / \mathrm{B} ; 8.9 \% \mathrm{C} / \mathrm{Y}\end{array}$ \\
\hline & $300-330$ & Ri 0 & 0 (S0) & 13.7 & $\begin{array}{c}5.59 \mathrm{MPa} \\
16.0 \% \mathrm{~A} / \mathrm{B} ; 84.0 \% \mathrm{C} / \mathrm{Y}\end{array}$ \\
\hline \multirow{3}{*}{$\mathrm{C}$} & $300-340$ & Ri 0 & 0 (S0) & $\begin{array}{c}\text { Total } \\
\text { disbondment }\end{array}$ & $\begin{array}{l}3.59 \mathrm{MPa} \\
100 \% \mathrm{~A} / \mathrm{B}\end{array}$ \\
\hline & $295-355$ & Ri 0 & 0 (S0) & $\begin{array}{c}\text { Total } \\
\text { disbondment }\end{array}$ & $\begin{array}{l}4.94 \mathrm{MPa} \\
100 \% \mathrm{~A} / \mathrm{B}\end{array}$ \\
\hline & $305-340$ & Ri 0 & 0 (S0) & $\begin{array}{c}\text { Total } \\
\text { disbondment }\end{array}$ & $\begin{array}{l}5.06 \mathrm{MPa} \\
100 \% \mathrm{~A} / \mathrm{B}\end{array}$ \\
\hline
\end{tabular}

Key: A: substrate; B: first coat; C: second coat; Y: glue; Z: dolly.

Specimens for B and C conditions presented underfilm corrosion as shown in Figure 2, in regions of adhesion failure and disbondment in the specimens, endorsing the development of subcutaneous oxidation in the presence of chlorides.
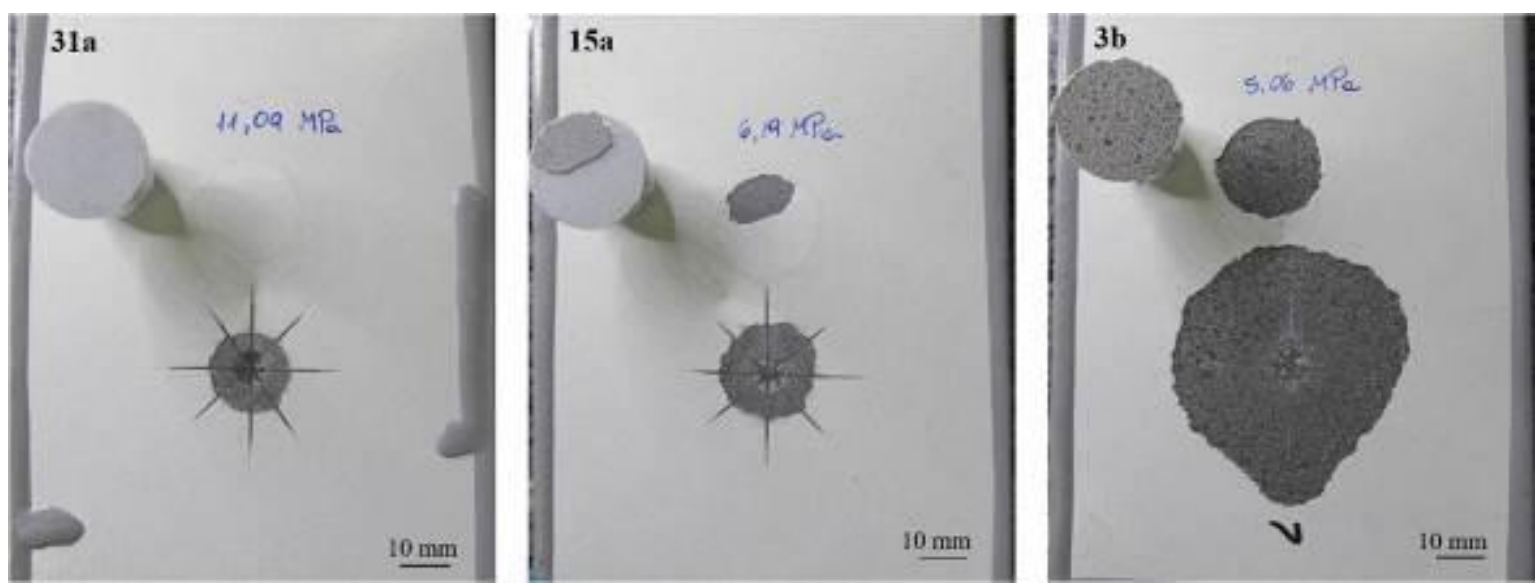

Figure 2: Specimens 31a (condition A), 15a (condition B) and 3b (condition C), respectively after delamination around the circular defect and the pull-off adhesion test.

\subsection{Immersion in deionized water at $40 \stackrel{\circ}{C}$}

Table 9 shows the performance results of the test specimens obtained in the immersion test in deionized water at $40^{\circ} \mathrm{C}$.

The pull-off adhesion after immersion ending was not performed due to the high quantity of blisters and consequent absence of a flat surface, as recommended by ISO 4624 [33]. 
Table 9: Results of specimens immersed in deionized water at $40^{\circ} \mathrm{C}$ for 480 hours

\begin{tabular}{c|c|c|c}
\hline CONDITION & DFT $(\boldsymbol{\mu m})$ & RUSTING DEGREE & BLISTERING DEGREE \\
\hline \multirow{4}{*}{ A } & $295-320$ & Ri 0 & $4(\mathrm{~S} 3)$ \\
\cline { 2 - 4 } & $300-330$ & Ri 0 & $4(\mathrm{~S} 3)$ \\
\cline { 2 - 4 } & $280-340$ & Ri 0 & 3 (S3) \\
\hline \multirow{4}{*}{ B } & $275-310$ & Ri 0 & $3(\mathrm{~S} 5)$ \\
\cline { 2 - 4 } & $285-320$ & Ri 0 & $3(\mathrm{~S} 5)$ \\
\cline { 2 - 4 } & $295-340$ & Ri 0 & $3(\mathrm{~S} 5)$ \\
\hline \multirow{4}{*}{ C } & $295-335$ & Ri 0 & $4(\mathrm{~S} 5)$ \\
\cline { 2 - 4 } & $255-305$ & Ri 0 & $3(\mathrm{~S} 5)$ \\
\cline { 2 - 4 } & $290-330$ & Ri 0 & \\
\hline
\end{tabular}

Underfilm corrosion was observed after removing the paint film as shown in Figure 3.
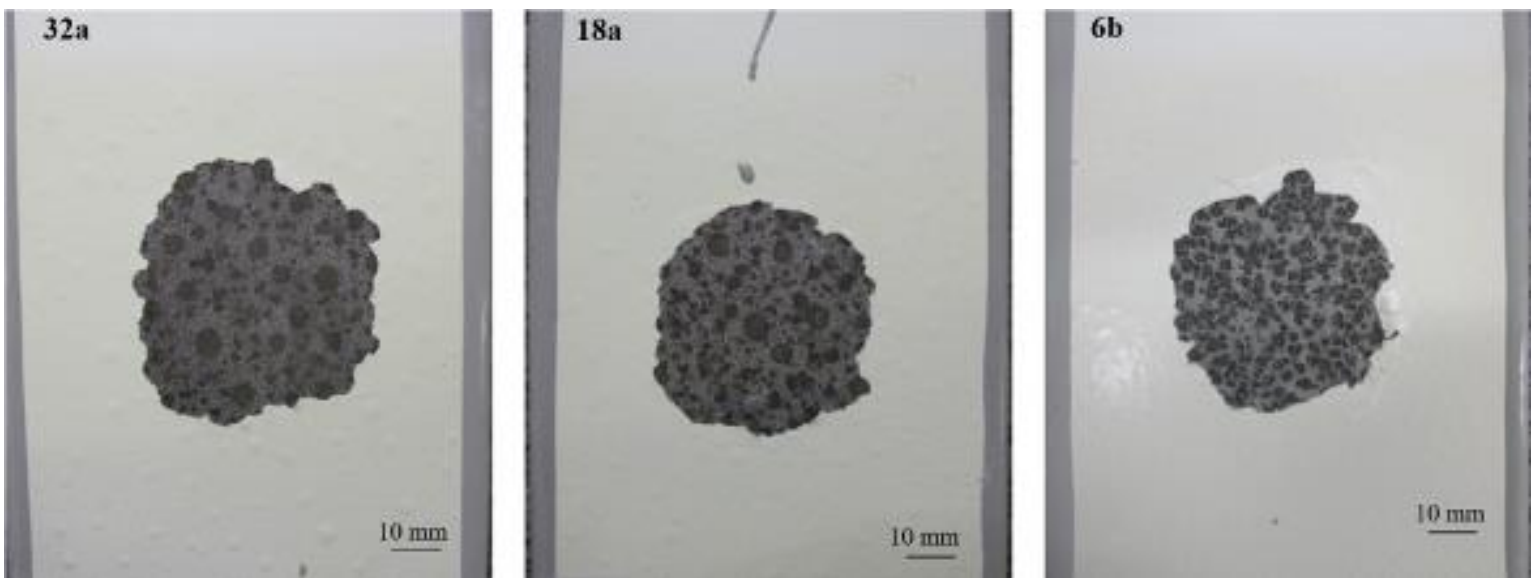

Figure 3: Underfilm corrosion in specimens 32a (condition A), 18a (condition B) and 6b (condition C), respectively.

\subsection{Cyclic corrosion test}

The results of cyclic corrosion test are shown in Table 10.

Table 10: Cyclic corrosion test results after 4200 hours

\begin{tabular}{|c|c|c|c|c|c|}
\hline CONDITION & DFT $(\mu \mathrm{m})$ & $\begin{array}{l}\text { RUSTING } \\
\text { DEGREE }\end{array}$ & $\begin{array}{l}\text { BLISTERING } \\
\text { DEGREE }\end{array}$ & $\begin{array}{l}\text { CORROSION AROUND } \\
\text { THE SCRIBE }(\mathrm{mm})\end{array}$ & $\begin{array}{c}\text { PULL-OFF } \\
\text { STRENGTH } \\
\text { AFTER TEST }\end{array}$ \\
\hline \multirow{3}{*}{ A } & $268-321$ & Ri 0 & 0 (S0) & 11.83 & $\begin{array}{l}9.84 \mathrm{MPa} \\
100 \% \mathrm{C} / \mathrm{Y}\end{array}$ \\
\hline & $255-323$ & Ri 0 & 0 (S0) & 11.65 & $\begin{array}{l}9.64 \mathrm{MPa} \\
100 \% \mathrm{C} / \mathrm{Y}\end{array}$ \\
\hline & $278-307$ & Ri 0 & 0 (S0) & 15.53 & $\begin{array}{l}9.24 \mathrm{MPa} \\
100 \% \mathrm{C} / \mathrm{Y}\end{array}$ \\
\hline \multirow{3}{*}{ B } & $291-310$ & Ri 0 & $0(\mathrm{~S} 0)$ & 15.15 & $\begin{array}{l}6.75 \mathrm{MPa} \\
100 \% \mathrm{C} / \mathrm{Y}\end{array}$ \\
\hline & $293-317$ & Ri 0 & $0(\mathrm{~S} 0)$ & 13.83 & $\begin{array}{l}7.15 \mathrm{MPa} \\
100 \% \mathrm{C} / \mathrm{Y}\end{array}$ \\
\hline & $291-333$ & Ri 0 & 0 (S0) & 14.49 & $\begin{array}{l}8.60 \mathrm{MPa} \\
100 \% \mathrm{C} / \mathrm{Y}\end{array}$ \\
\hline \multirow{3}{*}{ C } & $298-355$ & Ri 0 & 0 (S0) & 16.03 & $\begin{array}{c}6.60 \mathrm{MPa} \\
36.5 \% \mathrm{~A} / \mathrm{B} ; 63.5 \% \mathrm{C} / \mathrm{Y} \\
\end{array}$ \\
\hline & $301-360$ & Ri 0 & 0 (S0) & 12.38 & $\begin{array}{c}6.21 \mathrm{MPa} \\
22.8 \% \mathrm{~A} / \mathrm{B} ; 77.2 \% \mathrm{C} / \mathrm{Y}\end{array}$ \\
\hline & $299-340$ & Ri 0 & 0 (S0) & 17.35 & $\begin{array}{c}9.68 \mathrm{MPa} \\
21.6 \% \mathrm{~A} / \mathrm{B} ; 78.4 \% \mathrm{C} / \mathrm{Y}\end{array}$ \\
\hline
\end{tabular}


Key: A: substrate; B: first coat; C: second coat; Y: glue; Z: dolly.

\section{DISCUSSION}

\subsection{Soluble salts contents}

An initial value of $13.4 \mathrm{mg} / \mathrm{m}^{2} \mathrm{NaCl}$ even before intentional contamination can be attributed to atmospheric contaminants deposition on the surface of the test specimens prior to blasting, or even to steel grit used as abrasives $[1,44]$. Abrasives themselves can contain salts at their sources, transport vessels, storage environments and so on, which contributes to the amount of soluble salts deposited on surface [45].

According to Appleman [14], dry abrasive blasting is only a mechanical technique incapable of removing the microcrystals from the salts deposited in the steel. Johnson [46] explains that chloride ions form strong electrochemical bonds with the metal surface, so it is difficult to extract them. Fuente et al. [7] states that the percentage of soluble salts extraction from a dry sandblasted surface to the Sa $2 \frac{1}{2}$ degree is about $84 \%$, i.e., this surface preparation method does not completely remove the present salts.

For the Condition (C), the sample standard deviation was relatively higher which can be ascribed to some local accumulation of salts during the spreading of the contamination solution, or even by the blasting process.

On one hand, the droplet and spreading method for laboratory contamination is the most convenient and safe way to obtain pre-established levels of salts in a sample comparing to the exposure procedure in natural weathering or corrosion test chamber, i.e., salt spray chambers [7, 47]. On the other hand, this method provides crystal size and distribution less homogeneous than by spraying [19]. The slight deformation suffered by some specimens during the blast-cleaning may have affected the spreading of the contamination solution on the surface and contributed to a greater heterogeneity between the salt contents measured, as in Condition $\mathrm{C}$, with a larger standard deviation.

Moreover, the extraction method itself presents a considerably varied percentage of extraction, from 22 to $150 \%$, according to literature data collected by Appleman [48], what could contribute to the variation in the values collected, even though ISO 8502-6 [29] states that approximately 95\% of soluble salts are satisfactorily dissolved by re-injecting the solvent into the compartment for just four times.

\subsection{Pull-off adhesion test}

Failures were predominantly of adhesive nature between the topcoat and the adhesive used to glue dollies. So, the strength magnitude was not a response to the contamination level, just of the interaction/compatibility between glue and paint, which fully corroborate with Lee et al. [23]. However, in Condition (C), it was observed a small failure of type A/B (first coat/substrate), due to a likely accumulation of salts as explained below.

The difference between the soluble salts levels did not affect the adhesion of the coating system. Exposure to moisture and occurrence of osmosis are need so that the effects of salt contamination will be noted $[19,44]$.

\subsection{Cathodic disbondment by impressed current}

Increasing the soluble salts content also raised the disbondment around the circular defect and the A/B (substrate/ coating) failure percentage. As observed (Table 8) the adhesion strength decreased as the soluble salts level increased, in agreement with Morcillo [6] and with the results of a linear tendency found by Axelsen and Knudsen [24].

Based on cathodic disbondment results the maximum allowable salt contamination level for the coating system used might be within the range of approximately 13 to $50 \mathrm{mg} / \mathrm{m}^{2} \mathrm{NaCl}$.

The presence of soluble contaminants increases the conductivity of the electrolyte in the region where the paint is displaced, intensifying the reaction process with proportional decreasing of the adhesion and delamination increasing [24].

There was water penetration through the film evidenced by the formation of underfilm corrosion, but blistering was not observed because the hydraulic pressure caused by water was not enough to cause a perceptible deformation in the bubble form. Although, Lee et al. [23] have observed blisters for all contamination ranges considering the results of "system C" like the one applied on the present work. Thus, even similar paint systems can present anticorrosive performance completely different once blisters development is either 
a response of paint viscoelasticity or its deformation mechanism [19].

\subsection{Immersion in deionized water at $40^{\circ} \mathrm{C}$}

In the immersion test, unexpectedly all specimens showed blisters within 480 hours of test, ending it ahead of scheduled. This behaviour can be explained by the high concentration gradient, elevated temperature and the coating system porosity that facilitates water diffusion. The safe soluble salts content based on these results might be lower than $13 \mathrm{mg} / \mathrm{m}^{2} \mathrm{NaCl}$.

Lee et al. [23] observed failure of the epoxy coating system fully blasted only at $200 \mathrm{mg} / \mathrm{m}^{2} \mathrm{NaCl}$ in immersion condition at $40{ }^{\circ} \mathrm{C}$, using natural seawater, after testing for 5 months. This completely different performance compared to the results of this work can be easily explained by the concentration of salts in the test media. Since osmosis happens due to a concentration gradient, a media like natural seawater that already contains a salts concentration creates a smaller driven force than deionized water [16].

Low cross-linked regions in the paint film, even after the curing time specified by the manufacturer may had become percolating pathways for water and $\mathrm{O}_{2}$ through the coating during test, as suggested for Lyon et al. [10].

For Conditions B and C (Table 9), the blistering development in the same quantity and size suggests that the formation rate for levels above $13 \mathrm{mg} / \mathrm{m}^{2} \mathrm{NaCl}$ is similar, in this case.

The barrier protection effect is clearly observed in the second specimen of condition C (Table 9), given the development of larger and bigger number of blisters in a smaller dry film thickness $(255-305 \mu \mathrm{m})$ when compared to the others of the same group (condition $\mathrm{C}$ ).

Axelsen and Knudsen [24] found a defined time interval of 85, 60 and 5 days, respectively, for the development of blistering between test specimens applied with clear epoxy and with contamination levels of approximately 6, 40 and $127 \mathrm{mg} / \mathrm{m}^{2} \mathrm{NaCl}$. Conversely, in this work blisters appeared at all levels of salt contents within the inspection interval, between 14 and 20 days of testing. This fact suggests that the level of acceptable contamination on a surface is particularly dependent of the coating formulation and its intrinsic polymeric heterogeneity [9, 18]. Lee et al. [23] corroborate by concluding in their work that a reliable value of soluble salt depends on applied coating system, environmental and substrate condition.

There are significant differences in the maximum allowable levels of soluble salts according to the data for two coats epoxy systems in water immersion tests presented by ISO/TR 15235 [1]. In table A.1 of this standard, the level of soluble salts considered safe is $115 \mathrm{mg} / \mathrm{m}^{2} \mathrm{NaCl}$. In Tables C.1 and C.2, nine of thirteen coating manufacturers recommend values between 82 and $115 \mathrm{mg} / \mathrm{m}^{2} \mathrm{NaCl}$, two other manufacturers up to 49 and only one up to $16 \mathrm{mg} / \mathrm{m}^{2} \mathrm{NaCl}$. On the other hand, the results found in the present study shows that there was a failure even at the lowest evaluated value, about $13.4 \mathrm{mg} / \mathrm{m}^{2} \mathrm{NaCl}$.

Additionally, it is observed that the safety values recommended in these same tables for immersion situations are lower, less than half to the levels indicated for structures exposed to atmospheric conditions, probably due to the criticality of the immersion condition, as evidenced by this study and states by Tator [49].

\subsection{Cyclic corrosion}

Again, the corrosion around the scribe increased as soluble salts content also increased. But, underfilm corrosion affected the coating system adhesion just for the highest level considered in this study $\left(100 \mathrm{mg} / \mathrm{m}^{2} \mathrm{NaCl}\right)$. So, the allowable soluble salt content for this test might be between 50 and $100 \mathrm{mg} / \mathrm{m}^{2} \mathrm{NaCl}$.

Axelsen and Knudsen [24] otherwise, reported that the salt content had little or no effect on coating system with two coats of modified epoxy coating and a total coat thickness of $284 \pm 35 \mu \mathrm{m}$, exposed in a cyclic corrosion test.

The development of underfilm corrosion for condition $\mathrm{C}$, is different of what was reported by Baek et al. [15]. The authors did not observe this phenomenon in contaminated specimens with around $115 \mathrm{mg} / \mathrm{m}^{2}$ $\mathrm{NaCl}$, exposed in cyclic corrosion test. In their study, the corrosion around the scribe was smaller than $3 \mathrm{~mm}$, within the contamination range mentioned above, contrasting our findings as shown in Table 10.

Lee at al. [23] have suggested the cathodic disbondment test is the most reliable way to find the maximum allowable soluble salt level. Nevertheless, it is more reasonable to expose a coating system to determine a permissible level based on tests that closely simulate the real service conditions. If a system will not be used together with cathodic protection and it will be exposed in natural weathering conditions, the maximum allowable limit can be higher as discussed this work. 


\section{CONCLUSIONS}

In the present study, we demonstrated that pull-off adhesion strength without any exposure to a corrosive atmosphere, in order to promote osmosis, was not able to provide results in response to the levels of the substrate contamination with soluble salts.

The results show that, for the coating system studied, NORSOK M-501 3B, a soluble salts content above $20 \mathrm{mg} / \mathrm{m}^{2} \mathrm{NaCl}$ significantly compromises the performance in accelerated corrosion tests. In cathodic disbondment and cyclic corrosion tests, adhesion failures due to water penetration and underfilm oxidation occurred proportionally to the salt content used.

Considering the bibliographical survey carried out, as well as the results of this work, it was not possible to define a critical soluble salts content, satisfactory and safe, for different corrosive atmospheres to which a painted steel structure may be exposed in service, even for an epoxy coating system worldwide studied on similar conditions of preparation and tests.

In addition, it is important to mention that different coating systems behave equally in a differentiated manner on salts residues and exposure conditions. In this way, the choice and specification of a maximum soluble salts content should be made with great caution, considering a test protocol as closer as possible to the actual service conditions in which a coating system will be exposed.

The most recommended and safe practice is to work at the lowest soluble salt content as possible.

\section{ACKNOWLEDGEMENTS}

The authors are grateful to WEG Tintas Ltda and University of the Region of Joinville (UNIVILLE) for financial assistance and scholarships at the beginning of the research.

\section{BIBLIOGRAPHY}

[1] ISO - INTERNATIONAL STANDARD ORGANIZATION. "ISO/TR 15235: Preparation of steel substrates before application of paints and related products - Collected information on the effect of levels of water-soluble salt contamination”, Switzerland, 2001.

[2] BATES, C. R., "Has the critical art of surface preparation for pipecoating been forgotten", Journal of Protective Coatings \& Linings, v. 21, n. 8, pp. 26-34, Aug. 2004.

[3] MCKEEN, L. W., Fluorinated Coatings and Finishes Handbook, $2^{\text {nd }}$ ed., Oxford, England, Elsevier, 2016.

[4] JOHNSON, J. R., “soluble salts and specifications”, Coatings Pro Magazine, v.8, n. 2, pp. 2-6, Mar. 2008.

[5] FRANKHUIZEN, N., "Measuring $\mathrm{NaCl}$, salt, and soluble contaminants with bresle patches - Part 1", Coatings \& Linings, pp. 36-39, Nov. 2009.

[6] MORCILLO, M., "Soluble salts: their effect on premature degradation of anticorrosive paints", Progress in Organic Coatings, v. 36, pp. 137-147, 1999.

[7] FUENTE, D., CHICO, B., MORCILLO, M., "The effects of soluble salts at the metal/paint interface: advances in knowlegde", Portugaliae Electrochimica Acta, v. 24, pp. 191-206, 2006.

[8] FUENTE, D., BOHM, M., HOUYOUX, C., et al., "The settling of critical levels of soluble salts for painting”, Progress in Organic Coatings, v. 58, pp. 23-32, 2007.

[9] FRANKHUIZEN, N., "Measuring $\mathrm{NaCl}$, salt, and soluble contaminants with bresle patches - Part 2", Coatings \& Linings, pp. 34-37, Dec. 2009.

[10] LYON, S. B., BINGHAM, R., MILLS, D. J., "Advances in corrosion protection by organic coatings: what we know and what we'd like to know”, Progress in Organic Coatings, v. 102, Part A, pp. 2-7. Jan. 2017.

[11] NUNES, L. P. A., LOBO, C. O., Pintura Industrial na Proteção Anticorrosiva, $4^{\text {th }}$ ed., Rio de Janeiro, Brazil, Interciência, 2012.

[12] GENTIL, V., Corrosão, $6^{\text {th }}$ ed., Rio de Janeiro, Brazil, LTC, 2012.

[13] FAZENDA, J. M. R. (Coord.), "Pintura de manutenção industrial”, In: Tintas \& Vernizes: Ciência e Tecnologia, $3^{\text {th }}$ ed., chapter 22, São Paulo, Brazil, Edgard Blücher, 2005.

[14] APPLEMAN, B. R., Painting over soluble salts: a perspective, Paint Square, 1987. 
[15] BAEK, K. K., PARK, C. S., KIM, K. H., et al., "Effect of surface contaminants remained on the blasted surface on epoxy coating performance and corrosion resistance", Corrosion Science and Technology, v. 43, n. 25, pp. 27-32, 2006.

[16] SMITH, F. H., "Field joint coating of pipelines - effect of soluble salt contamination on 2-layer heat shrink sleeve performance”, Anti-Corrosion Methods and Materials, v. 63, n. 2, pp. 105 - 115, 2016.

[17] STINER, H. "Soluble Salts and Coating Performance", CORROSIONPEDIA, https://www.corrosionpedia.com/soluble-salts-and-coating-performance/2/6502. Accessed in July 2017.

[18] Peters, H. "Salt Limits to Prevent Premature Coating Failures", CORROSIONPEDIA, https://www.corrosionpedia.com/2/4754/soluble-salts/salt-limits-to-prevent-premature-coating-failures. Accessed in July 2017.

[19] FUENTE, D., ROHWERDER, M., "Fundamental investigation on the stability of the steel/coating interfaces contaminated by submicroscopic salt particles", Progress in Organic Coatings, v. 61, n. 2, pp. 233-239, Feb. 2008.

[20] IMO - INTERNATIONAL MARITIME ORGANIZATION - MARITIME SAFETY COMMITTEE. "IMO MSC.215 (82): Performance standard for protective coatings for dedicated seawater ballast tanks in all types of ships and double-side skin spaces of bulk carriers", United States of America, 2006.

[21] NORSOK STANDARD. "NORSOK M-501: Surface preparation and protective coating”, Norway, 2012. [22] MÜLLER, B., POTH, U., Coatings Formulation: An International Textbook., $2^{\text {nd }}$ ed., Hanover, Germany, Vincentz, 2012.

[23] LEE, C.H., SON, S. M., BAEK, Y. H., KIM, D. Y., "Soluble salt criteria of epoxy coatings for ship's water ballast tank", NACE International Corrosion Conference \& Expo, 10017, San Antonio, Texas, United States of America, 2010.

[24] AXELSEN, S. B., KNUDSEN, O. Ø., "The effect of water-soluble salt contamination on coating performance", NACE International Corrosion Conference \& Expo, 11042, Dallas, Texas, United States of America, Mar. 2011.

[25] ISO - INTERNATIONAL STANDARD ORGANIZATION. "ISO 8501-1: Preparation of steel substrates before application of paints and related products - visual assessment of surface cleanliness -- part 1: rust grades and preparation grades of uncoated steel substrates after overall removal of previous coatings". Switzerland, 2007.

[26] FLORES, S., SIMANCAS, J., MORCILLO, M., "Methods for samplings and analyzing soluble salts on steel surfaces: a comparative study", Paint Square, 1994.

[27] FUENTE, D., FLORES, S., MORCILLO, M., "Deterioration of paint systems applied on zinc substrates contaminated with soluble salts”, Progress in Organic Coatings, v. 41, pp. 183-190, Feb. 2001.

[28] PINHO, S. P., MACEDO, E. A., "Solubility of $\mathrm{NaCl}, \mathrm{NaBr}$, and $\mathrm{KCl}$ in Water, Methanol, Ethanol, and Their Mixed Solvents", Journal of Chemical Engineering, v. 50, pp. 29-32, 2005.

[29] ISO - INTERNATIONAL STANDARD ORGANIZATION. "ISO 8502-6: Preparation of steel substrates before application of paints and related products - Tests for the assessment of surface cleanliness -Part 6: Extraction of soluble contaminants for analysis - The Bresle Method”. Switzerland, 2006.

[30] ISO - INTERNATIONAL STANDARD ORGANIZATION. "ISO 8502-9: Preparation of steel substrates before application of paints and related products - Tests for the assessment of surface cleanliness -Part 9: Field method for the conductometric determination of water - soluble salts". Switzerland, 1998.

[31] ISO - INTERNATIONAL STANDARD ORGANIZATION. "ISO 19840 Paints and varnishes -- Corrosion protection of steel structures by protective paint systems -- Measurement of, and acceptance criteria for, the thickness of dry films on rough surfaces”. Switzerland, 2012.

[32] ISO - INTERNATIONAL STANDARD ORGANIZATION. "ISO 2812-2: Paints and varnishes - Determination of resistance to liquids -- Part 2: Water immersion method". Switzerland, 2007.

[33] ISO - INTERNATIONAL STANDARD ORGANIZATION. "ISO 4624: Paints and Varnishes - Pull off test for adhesion". Switzerland, 2002.

[34] ASTM - AMERICAN SOCIETY FOR TESTING AND MATERIALS. “ASTM G-8: Test Methods for Cathodic Disbonding of Pipeline Coatings". West Conshohocken, United States of America 1996.

[35] ISO - INTERNATIONAL STANDARD ORGANIZATION. "ISO 20340: Performance requirements for protective paint systems for offshore and related structures", Switzerland, 2009. 
[36] ISO - INTERNATIONAL STANDARD ORGANIZATION. "ISO 4628-3: Paints and varnishes - Evaluation of degradation of coatings - Designation of quantity and size of defects, and of intensity of uniform changes in appearance -- Part 3: Assessment of degree of rusting", Switzerland, 2016.

[37] ISO - INTERNATIONAL STANDARD ORGANIZATION. "ISO 4628-2: Paints and varnishes - Evaluation of degradation of coatings - Designation of quantity and size of defects, and of intensity of uniform changes in appearance -- Part 2: Assessment of degree of blistering", Switzerland, 2016.

[38] DEFELSKO, http://www.defelsko.com/adhesion-tester/qa.htm. Accessed in June 2017.

[39] GREENFIELD, D., SCANTLEBURY, D., "The Protective action of organic coatings on steel: a review", The Journal of Corrosion Science and Engineering, v. 3. n. 5., Aug. 2000.

[40] MARTINEZ, S., ŽULJ, L. V., KAPOR, F., "Disbonding of underwater-cured epoxy coating caused by cathodic protection current". Corrosion Science, v. 51, n. 10, pp. 2253-2258, Oct. 2009.

[41] BOOCOCK, S., "Meeting industry needs for improved tests", Journal of Protective Coatings \& Linings, pp. 70-76, 1995.

[42] QUILL, J., GAUNTNER, S., FOWLER, S., REGAN, J., "Combined corrosion and weathering: validating a concept with over a decade of research", Q-lab Technical Article, LF-8160, 2013.

[43] ISO - INTERNATIONAL STANDARD ORGANIZATION. "ISO 9227: Corrosion tests in artificial atmospheres -- Salt spray tests", Switzerland, 2012.

[44] ISO - INTERNATIONAL STANDARD ORGANIZATION. "ISO 16474-3: Paints and varnishes -Methods of exposure to laboratory light sources -- Part 3: Fluorescent UV lamps". Switzerland, 2013.

[45] BORTAK, T. N., Guide to Protective Coatings: Inspection and Maintenance, United States of America, United States Department of the Interior, 2002.

[46] JOHNSON, J. R., "Removing Soluble Salts", Coatings Pro Magazine, v.8, n. 4, pp. 2-5, Jul. 2008.

[47] FUENTE, D., CHICO, B., MORCILLO, M., "Simulación en laboratorio mediante ensayos de corrosión acelerada de la presencia y contenido en sales solubles en los productos de corrosión atmosférica del acero", Revista de Metalurgia, v. Extr., pp. 438-432, 2005.

[48] APPLEMAN, B. R., "Advances in Technology and Standards for Mitigating the Effects of Soluble Salts", Journal of Protective Coatings \& Linings, v. 19, n. 5, pp. 42-47. May 2002.

[49] TATOR, K. B., "Soluble Salts and Coatings - An Overview - Part 1: A Summary of Recent Research on Allowable Amounts of Salts Tolerated beneath Coatings", Journal of Protective Coatings \& Linings, v. 27, n. 2, pp. 50-63, Feb. 2010.

\section{ORCID}

Camila Aparecida Zimmermann

http://orcid.org/0000-0001-9573-0900

Luciano André Deitos Koslowski

http://orcid.org/0000-0003-2917-8681

Maria Inês Siqueira Araújo

http://orcid.org/0000-0002-2157-5757

Marcia Luciane Lange Silveira

http://orcid.org/0000-0003-4616-8645 